\title{
Eksplorasi Jagung Lokal di Sulawesi Selatan dan Studi Pertumbuhannya di Kebun Penelitian Puslit Biologi, LIPI, Cibinong
}

\section{Local Corn Exploration in South Sulawesi and Study on Its Growth in Research Plot of Puslit Biologi, LIPI, Cibinong}

\author{
Albert Husein Wawo ${ }^{*}$, Peni Lestari ${ }^{1}$, Ninik Setyowati ${ }^{1}$ \\ ${ }^{1}$ Bidang Botani, Pusat Penelitian Biologi - LIPI, Jl. Raya Jakarta-Bogor Km 46 Cibinong 16911, Indonesia \\ Email :wawoal@yahoo.com *Penulis Korespondensi
}

\begin{abstract}
Most regions in Indonesia have local corn cultivars. South Sulawesi Province is one of the provinces in Indonesia which have a local corn cultivar, namely Jagung Pulut (Pulut-corn). Every district in this province has one or two cultivars of Pulut-corn that adapts well to its region. Cultivation techniques of Pulut-corn in every location differ from each other so that there is no enough data to conclude the best Pulut-corn cultivar for that area. This research aims to reveal the diversity of Pulut-corn from South Sulawesi, to gather information on its growth and production, and to decide the best Pulut-corn cultivars in South Sulawesi. A survey was carried out in several locations in South Sulawesi to obtain the Pulut-corn cultivars diversity. The research on the plant's growth was conducted at the Experimental Garden of the Research Center for Biology, LIPI. The study used a Randomized Block Design with three replications. The results showed that four cultivars from South Sulawesi were collected, namely Gowa, Pangkajene, Batarakamu and Batarakoasa. Batarakamu cultivar was recommended to be developed.
\end{abstract}

Keywords: pulut-corn, growth, production, Batarakamu, South Sulawesi.

\begin{abstract}
Abstrak
Sebagian besar daerah di Indonesia memiliki kultivar jagung lokal. Provinsi Sulawesi Selatan adalah salah satu provinsi di Indonesia yang memiliki kultivar jagung lokal yang disebut Jagung Pulut. Setiap kabupaten di provinsi ini memiliki satu atau dua kultivar jagung pulut yang telah beradaptasi baik dengan kondisi daerahnya. Cara budidaya jagung pulut antar lokasi berbeda-beda sehingga tidak cukup data untuk menyimpulkan kultivar jagung pulut terbaik untuk daerah tersebut. Penelitian ini bertujuan untuk mengungkapkan keanekaragaman jagung pulut dari Sulawesi Selatan dan menggali informasi pertumbuhan dan produksi; kami juga menetapkan kultivar jagung pulut terbaik dari Sulawesi Selatan. Penelitian untuk mendapatkan keanekaragaman jagung pulut dilakukan melalui survei pada beberapa lokasi di provinsi Sulawesi Selatan sedangkan penelitian pertumbuhan dilakukan di Kebun Penelitian Puslit Biologi, LIPI menggunakan Rancangan Acak Kelompok dengan 3 ulangan. Hasil penelitian menunjukkan telah terkoleksi 4 kultivar jagung pulut dari Sulawesi Selatan yaitu Kultivar Gowa, Pangkajene, Batarakamu dan Batarakoasa. Kultivar Batarakamu direkomendasikan untuk dikembangkan.
\end{abstract}

Kata Kunci: jagung pulut, pertumbuhan, produksi, Batarakamu, Sulawesi Selatan

Diterima: 24 April 2019, disetujui: 14 Mei 2019

\section{Pendahuluan}

Jagung (Zea mays L.) adalah tanaman semusim yang sudah lama dikenal di Indonesia, merupakan sumber pangan dunia terbesar setelah padi dan gandum. Sebelum tahun 1970, jagung menjadi salah satu makanan pokok masyarakat
Indonesia (Lestari dan Farid, 2017). Seiring meluasnya industri pakan ternak dan beralihnya preferensi makanan pokok masyarakat Indonesia ke beras, maka peningkatan kebutuhan butiran jagung bukan lagi untuk makanan pokok, tetapi beralih ke camilan, minyak sayur, tepung; dan pakan ternak. Biomass tanaman jagung berupa 
batang dan daun digunakan untuk pupuk hijau dan pakan ternak. Tercatat konsumsi jagung di Indonesia pada tahun 1968 sekitar 26,2 kg per kapita (Pakpahan, 2007) dan pada tahun 2018 meningkat untuk bahan pangan sebesar 434,625 ton, sedangkan kebutuhan untuk pakan mencapai angka 10.820.000 ton (Sabarella et al, 2018). Dengan gambaran demikian, swasembada jagung menjadi salah satu sasaran utama pengembangan bidang pangan tahun 2017 hingga tahun 2019.

Areal pertanaman jagung umumnya berada pada daerah kering, yang kurang optimum untuk budidaya padi dan komoditas hortikultura, karena tanaman jagung dapat beradaptasi luas, mulai lahan optimum hingga lahan marjinal dengan tingkat ketersediaan air yang rendah dan suhu yang lebih tinggi (Wirosoedarmo et al, 2011). Di Indonesia terdapat banyak varietas jagung hasil persilangan (jagung hibrida) dan kultivar jagung lokal yang toleran kekeringan (Meneg Ristek, 1981). Kultivar jagung lokal memiliki beberapa keunggulan yaitu toleran kekeringan, berumur genjah, memiliki kelobot tebal untuk melindungi butiran jagung dari gangguan hama; serta rasa yang sangat spesifik, sesuai selera masyarakat setempat.

Jagung memiliki keanekaragaman yang tinggi karena daerah pembudidayaannya sangat luas (Yasin et al, 2016). Kultivar jagung lokal di Indonesia tersebar di berbagai daerah antara lain, Bali, Jawa Tengah, Jawa Timur, Flores, Alor, dan Sulawesi Selatan. Wawo et al, (2018) melaporkan bahwa kultivar jagung lokal Bali menunjukkan hasil biji jagung pipilan lebih rendah dari varietas unggul nasional yaitu Bima, Gumarang, dan Srikandi. Di Kecamatan Nangaroro, Flores, terdapat kultivar jagung lokal yang disebut kultivar Jawa dera memiliki umur genjah, hanya 8-9 minggu; produksinya rendah. Jagung ini biasa ditanam 2-3 minggu sebelum awal musim hujan untuk mengatasi kekurangan pangan / kelaparan pada saat olah tanah dan masa penantian panen jagung hibrida. Kartasapoetra (1988) menyatakan bahwa masalah klasik pada kultivar lokal adalah produksi rendah.

Masyarakat Sulawesi Selatan juga mengenal kultivar jagung lokal yang memiliki kandungan amilopektin lebih tinggi; rasanya manis dan pulen (Tengah et al, (2017) dan Rouf et al, (2010) menyebutnya Jagung Pulut. Setiap hari penduduk memakan jagung pulut sebagai camilan atau sebagai bekal dalam perjalanan antar kota di Sulawesi Selatan. Di Jepang, Jagung pulut dibudidayakan intensif untuk industri makanan, bahan baku produk tekstil, lem dan industri kertas.

Pustaka mengenai jagung pulut yang berhasil diperoleh antara lain; Respon tanaman ini terhadap pemupukan untuk meningkatkan hasilnya (Juhaeti et al, 2013; Herawati et al, 2015; Tengah et al, 2017). Beberapa studi mengai persebaran jagung pulut di Pulau Sulawesi meliputi Sulawesi Selatan (Maruapey, 2012; Herawati et al, 2015), Sulawesi Tenggara (Safuan et al, 2014), Sulawesi Tengah (Wijayanto, 2007., Muchtar, 2018), Sulawesi Barat (Juhriah et al, 2013), Sulawesi Utara (Tengah et al, 2017) dan Gorontalo (Rouf et al, 2010). Program pemuliaan jagung pulut mulai dilaporkan pada beberapa tahun terakhir yakni laporan mengenai keragaman jagung pulut (Fiddin et al, 2018), uji stabilitas galur-galur jagung pulut (Yasin et al, 2017). Meskipun telah diperoleh informasi persebaran jagung pulut di Sulawesi Selatan, tetapi informasi pertumbuhan dan produksinya belum ada. Informasi ini dapat diperoleh secara akurat jika benih-benih kultivar jagung pulut tersebut ditumbuhkan secara bersama-sama dalam lingkungan tumbuh yang homogen. Dengan mengetahui informasi pertumbuhan, dapat ditetapkan varietas lokal unggul yang dapat dikembangkan lebih luas di masa mendatang.

Eksplorasi untuk mengoleksi kultivar jagung lokal dan mempelajari pertumbuhannya adalah sebuah kegiatan penting untuk mencegah kehilangan sumber daya hayati lokal (plasma nutfah) yang telah dikenal baik oleh masyarakat (Meneg Ristek, 1981., Yasin et al, 2007). Kegiatan penelitian yang berjudul Eksplorasi Jagung Lokal di Sulawesi Selatan dan Studi pertumbuhannya perlu dilaksanakan. Penelitian ini bertujuan untuk mengungkap informasi keanekaragaman jagung lokal dan pertumbuhannya serta menetapkan kultivar jagung lokal terbaik yang berasal dari provinsi Sulawesi Selatan. 


\section{Metode Penelitian}

Penelitian ini terdiri dari 2 tahap yaitu penelitian keanekaragaman jagung lokal di provinsi Sulawesi Selatan dan Studi fisiologi pertumbuhannya. Pada penelitian keanekaragaman jagung pulut, dilakukan eksplorasi pada beberapa lokasi yang memiliki kebun jagung pulut dan tempat-tempat istirahat berupa restoran yang menjual rebusan jagung pulut dan dilakukan wawancara dengan penduduk setempat. Selain dikumpulkan informasi tentang nama-nama kultivar jagung pulut, juga dikumpulkan benih jagung pulut dari masing-masing lokasi dan dibawa ke LIPI Cibinong untuk pengujian pertumbuhannya. Beberapa lokasi di provinsi Sulawesi Selatan yang dikunjungi adalah Kabupaten Maros, Gowa, Takalar, Jeneponto, Pangkajene dan Barru.

Studi fisiologi pertumbuhan jagung lokal dari Sulawesi Selatan dilaksanakan di Kebun Penelitian Puslit Biologi, LIPI Cibinong. Bahan penelitian berupa benih jagung pulut hasil eksplorasi. Penelitian ini dipolakan secara Rancangan Acak kelompok dengan 3 ulangan sehingga terdapat 12 petak (Hanafiah, 2002). Setiap petak penelitian yang berukuran $100 \mathrm{~m}^{2}$ ditanami jagung dari masing-masing kultivar. Jarak tanam jagung $80 \mathrm{~cm} \times 50 \mathrm{~cm}$. Setiap lubang ditanami 1 butir jagung sehingga setiap petak terdapat 230 tanaman. Setiap petak dipilih 10 tanaman sebagai obyek pengamatan yang terletak di tengah petak.

Parameter yang diamati adalah informasi pertumbuhan vegetatif dan pertumbuhan generatif. Informasi pertumbuhan vegetatif terdiri dari tinggi tanaman, diameter batang, jumlah daun, panjang / lebar daun, panjang akar dan jumlah akar, sedangkan informasi generatif berupa masa berbunga tanaman jagung, panjang malai, panjang dan diameter kelobot, tongkol dan produksi biji. Pengamatan dilakukan sekali dalam 2 minggu. Berat kering bagian tanaman diukur dengan menggunakan metode oven yaitu bagian-bagian tanaman dipotong lalu dikeringkan dengan menggunakan oven pada suhu $80^{\circ} \mathrm{C}$ sampai beratnya stabil. Data berat kering digunakan untuk analisis rasio(nisbah), berat daun (NBD), luas daun spesifik (LDS), indek luas daun (ILD) dan indeks ketebalan daun (IKD) menggunakan rumus yang disampaikan oleh Sitompul \& Guritno (1995). NBD = Berat daun total / Berat total tanaman. LDS = Luas daun total / Berat daun total. ILD = LDS / Jarak tanam $\left(\mathrm{cm}^{2}\right)$ dan IKD $=$ NBD $x$ LDS. Indeks Panen (IP) adalah ratio hasil berat kering ekonomi (biji) dengan berat total tanaman. Data hasil pegamatan dianalisis menggunakan software SAS versi 9.1.

\section{Hasil dan Pembahasan}

\section{Keanekaragaman Jagung lokal}

Jagung pulut di kabupaten Maros biasa ditanam pada lahan kosong yang berdekatan dengan Taman Nasional Batimurung serta lahan pertanian antara Kabupaten Maros dan Pangkajene. Jagung pulut di daerah ini hanya ditanam pada musim kering, karena petani menggunakan sawah tadah hujan untuk menanam padi di musim hujan sehingga saat eksplorasi tidak menemukan petani yang menanam jagung pulut.

Kabupaten Pangkajene terkenal sebagai penghasil jagung pulut yang mensuplai kebutuhan jagung pulut untuk daerah Maros dan Makasar. Penduduk kabupaten Pangkajene menanam jagung pulut di ladang yang terletak di daerah pegunungan dan di lahan sawah tadah hujan setelah tanaman padi dipanen. Di Kabupaten Pangkajene diperoleh benih jagung pulut kultivar lokal Pangkajene (Gambar 1g).

Kabupaten Gowa memiliki hamparan tanah kering yang luas dan memiliki sistem pengairan yang baik. Masyarakat di kabupaten ini suka memakan campuran nasi dan jagung sebagai makanan pokok, sehingga pada musim kering mereka menanam jagung di sawah tadah hujan. Masyarakat kabupaten Gowa menyimpan benih jagung pulut di atas para-para supaya benihnya bebas hama dan tetap kering (Gambar 1a). Di kampung Bili-Bili, kabupaten Gowa, diperoleh benih jagung pulut kultivar lokal Gowa (Gambar 1b).

Penduduk di Kabupaten Takalar tidak hanya menanam jagung pulut, tetapi juga jagung hibrida di sawah tadah hujan pada bulan September - November dan Desember - April 
dengan area penanaman yang cukup luas. Pada beberapa lokasi masyarakat menanam jagung pulut di tepi sungai dan tepi kanal drainase (Gambar $1 \mathrm{c}$ dan d).

Di kampung Benu, kecamatan Bengkala, Kabupaten Jeneponto; Jagung pulut ditanam 2 kali dalam setahun yaitu pada bulan September / Oktober dan pada bulan April/Mei, dan memang sebagian besar penduduk d Kabupaten Jeneponto berprofesi sebagai petani. Kawasan yang termasuk kategori lahan kering ini termasuk dataran rendah $(19 \mathrm{~m} \mathrm{dpl})$. Suhu udara siang hari di wilayah ini berkisar antara $38-40^{\circ} \mathrm{C}$. Umumnya petani menanam padi di sawah tadah hujan. Setelah padi dipanen penduduk memotong jerami padi kemudian lahan sawah langsung ditanami jagung pulut. Jagung pulut juga ditanam di ladang, baik pada musim hujan maupun musim marengan (sisa hari hujan). Di Kampung Benu terdapat 2 kultivar benih jagung pulut yang berhasil diperoleh yaitu kultivar Batarakoasa (pulut nasi) dan Batarakamu (pulut biasa) (Gambar 1 e dan f).

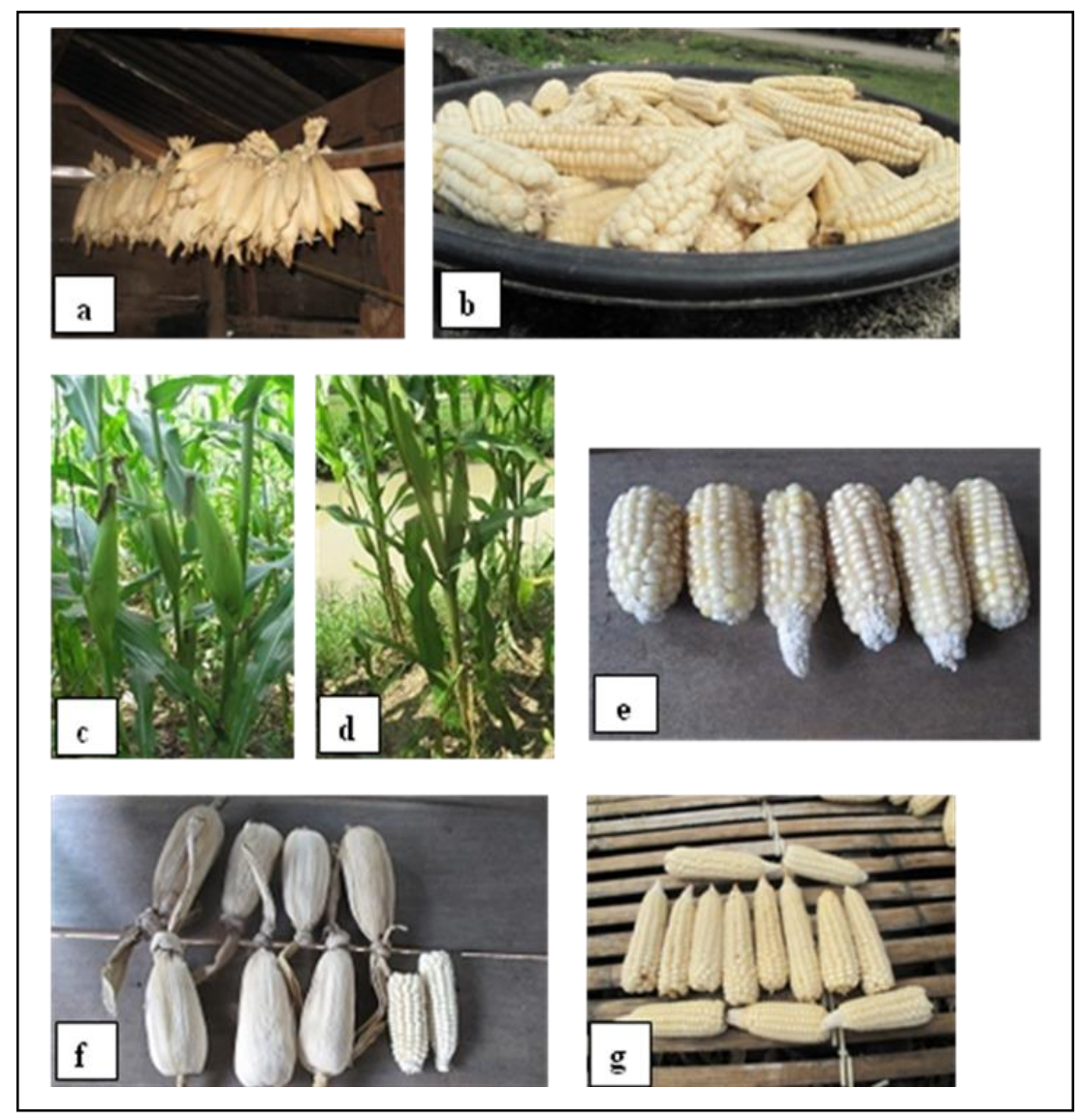

Gambar 1. Kultivar jagung pulut Sulawesi Selatan. (a dan $b=$ Cara menyimpan Benih dan mengeringkan benih Jagung pulut di Gowa; $\mathrm{c}$ dan $\mathrm{d}=$ Kebun jagung pulut milik masyarakat Takalar; e dan $\mathrm{f}=$ Kultivar Batarakoasa dan Batarakamu dari Jeneponto; $g$ = Kultivar Pangkajen

Di Kabupaten Barru petani menanam jagung pulut di sawah tadah hujan pada musim kering, sementara di musim hujan petani menanam jagung pulut di daerah pegunungan sehingga pada kesempatan ini tidak didapatkan benih jagung pulut dari lokasi ini.
Berdasarkan karakter daerah eksplorasi, diketahui bahwa komoditas jagung pulut hanya diusahakan pada lahan kering, dengan sistem budidaya tadah hujan. Penanaman umumnya hanya dilakukan di musim kering, kecuali di daerah Takalar yang juga mengusahakan pada musim penghujan. Eksplorasi di provinsi 
Sulawesi Selatan pada saat itu dilakukan di musim penghujan, sehingga hanya ditemukan 4 kultivar untuk dipelajari lebih lanjut pertumbuhannya. Keterbatasan mendapatkan plasma nutfah jagung pulut karena pemilihan waktu eksplorasi yang kurang tepat. Pada saat itu, sebagian besar petani tengah menanam padi dan jagung hibrida sehingga tidak dapat diidentifikasi petani mana saja yang menanam jagung pulut sebagai pergiliran tanaman padi atau jagung hibrida.Walaupun demikian telah diketahui bahwa pulau Sulawesi adalah daerah persebaran jagung pulut dan kaya akan keanekaragamannya.

\section{Pertumbuhan Jagung Pulut}

\section{Pertumbuhan tinggi}

Pertumbuhan tinggi batang 4 kultivar jagung lokal dari Sulawesi Selatan ditampilkan pada kurva pertumbuhan tinggi pada Gambar 2 berikut:

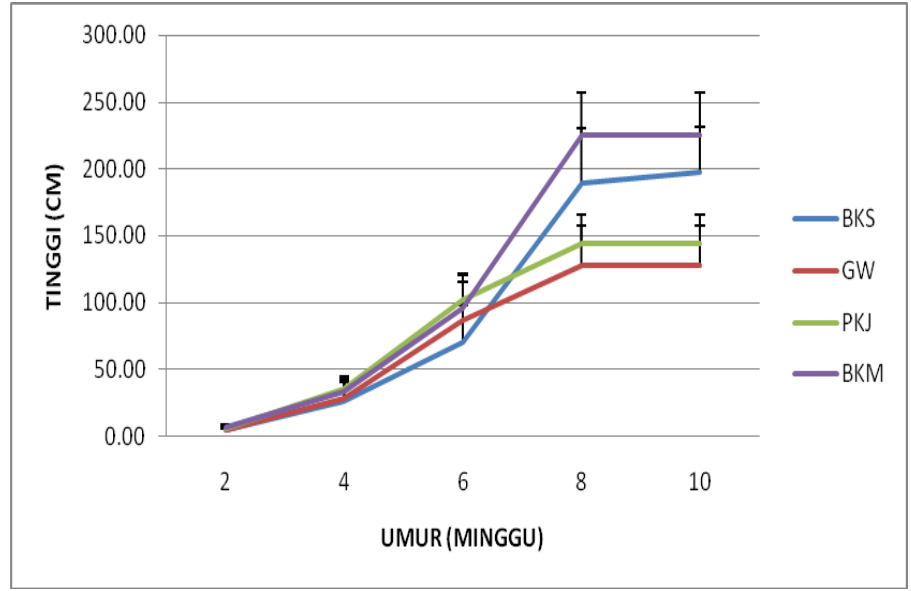

Gambar 2. Kurva pertumbuhan tinggi 4 kultivar Jagung pulut. $(\mathrm{BKS}=$ Batarakoasa, $\mathrm{GW}=$ Gowa, $\mathrm{PKJ}=$ Pangkajene, $\mathrm{BKM}=$ Batarakamu)

Pertumbuhan tinggi batang jagung pulut terlihat berbeda ketika tanaman jagung melewati umur 6 minggu setelah tanam. Pada saat tersebut tanaman jagung kultivar Batarakamu dan Batarakoasa memiliki pertambahan tinggi batang lebih besar daripada kultivar Gowa dan Pangkajene. Saharudin \& Nirwana (2008) mengatakan bahwa tinggi batang jagung pulut lokal berkisar antara $135-150 \mathrm{~cm}$. Pernyataan ini hanya cocok untuk kultivar Pangkajene dan Gowa, tapi tidak sesuai bagi kultivar Batarakamu dan Batarakoasa yang tinggi batangnya berkisar antara $198-224 \mathrm{~cm}$. Pada umur 8 minggu setelah tanam, pertumbuhan tinggi pada kultivar Gowa dan Pangkajene tidak bertambah lagi dikarenakan pada umur tersebut kedua kultivar jagung lokal ini telah berbunga.
Umumnya batang tersusun oleh buku dan ruas, perpanjangan ruas menyebabkan batang ini semakin panjang dan pada buku-buku tersebut tumbuh daun. Oleh karena itu, jumlah buku dan ruas sama dengan jumlah daunnya (Gardner et al, 1991).

Gardner et al, (1991) menjelaskan bahwa pertumbuhan tanaman dipengaruhi oleh faktor internal (genetik) dan faktor eksternal (lingkungan). Keempat kultivar jagung ini ditanam pada satu lokasi yang homogen maka dapat dipastikan bahwa perbedaan pertumbuhan keempatnya dipengaruhi oleh faktor genetik. Falconer dan Mackay (1996) menyatakan bahwa pengaruh genetik dapat diduga dari populasi yang ditanam pada lingkungan yang homogen. 
Albert Husein Wawo dkk.

Tabel 1. Pertumbuhan Diameter Batang (cm) dari 4 Kultivar Jagung Pulut

\begin{tabular}{lccccc}
\hline \multirow{2}{*}{ Kultivar } & \multicolumn{5}{c}{ Umur ( minggu) } \\
\cline { 2 - 6 } & $\mathbf{2}$ & $\mathbf{4}$ & $\mathbf{6}$ & $\mathbf{8}$ & $\mathbf{1 0}$ \\
\hline \hline Batarakoasa & $0,26 \pm 0,04$ & $1,06 \pm 0,38$ & $1,87 \pm 0,41$ & $1,87 \pm 0,41$ & $1,87 \pm 0,41$ \\
Gowa & $0,22 \pm 0,09$ & $0,97 \pm 0,34$ & $1,42 \pm 0,17$ & $1,42 \pm 0,17$ & $1,42 \pm 0,17$ \\
Pangkajene & $0,34 \pm 0,13$ & $1,36 \pm 0,27$ & $1,72 \pm 0,30$ & $1,72 \pm 0,30$ & $1,72 \pm 0,30$ \\
Batarakamu & $0,33 \pm 0,13$ & $1,39 \pm 0,45$ & $2,15 \pm 0,30$ & $2,15 \pm 0,30$ & $2,15 \pm 0,30$ \\
\hline \hline
\end{tabular}

Keterangan: Angka dibelakang \pm adalah nilai standar deviasi

Pertumbuhan tanaman juga dapat diamati dari penambahan ukuran batang. Keempat kultivar jagung lokal mengalami peningkatan diameter batang terjadi antara $2-6$ minggu setelah tanam (Tabel 1). Sesudah umur 6 minggu tidak terjadi pertumbuhan diameter batang pada semua kultivar jagung lokal. Diduga, pada saat itu tanaman mengalami fase peralihan, dari vegetatif ke generatif, sehingga asimilat yang dihasilkan pada umur setelahnya dikonsentrasikan untuk perpanjangan ruas batang, membentuk daun, bunga dan tongkol. Batang jagung yang memiliki diameter paling besar adalah kultivar Batarakamu, sedangkan yang paling kecil kultivar Gowa.

\section{Pertumbuhan daun}

Pada umur 2 - 3 minggu setelah tanam jumlah daun dari 4 kultivar jagung pulut ini tidak jauh berbeda. Perbedaan mulai terjadi ketika tanaman jagung memasuki umur 4 minggu, dan perbedaan jumlah daun menjadi semakin jelas ketika berumur 6-8 minggu setelah tanam. Pada umur $6-8$ minggu setelah tanam tidak terjadi penambahan jumlah daun pada semua kultivar jagung pulut karena pada umur tersebut semua kultivar jagung memasuk fase generatif (Tabel $5)$.

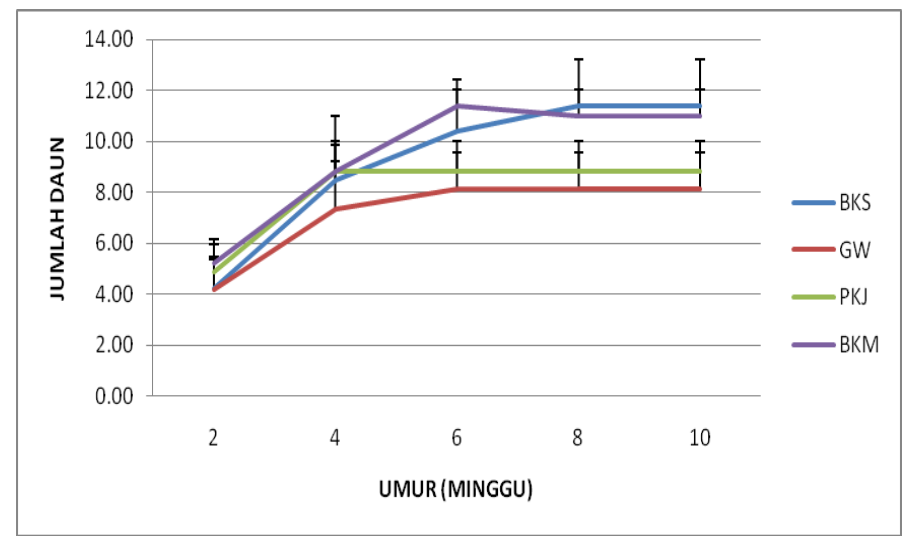

Gambar 3. Kurva pertumbuhan jumlah daun dari 4 kultivar jagung pulut. $(\mathrm{BKS}=$ Batarakoasa, $\mathrm{GW}=\mathrm{Gowa}, \mathrm{PKJ}=$ Pangkajene, $\mathrm{BKM}=$ Batarakamu)

Pertumbuhan jumlah daun jagung berkaitan dengan tinggi batangnya (Gardner et al, 1991). Oleh karena itu kultivar Batarakamu dan Batarakoassa yang memiliki perawakan yang tinggi, memiliki jumlah daun lebih banyak dibandingkan dengan Gowa dan Pangkajene yang memiliki perawakan lebih pendek (Gambar 3). Sejalan dengan hal tersebut, ukuran daun (panjang dan lebar) kultivar Batarakamu dan Batarakoassa juga lebih besar dibandingkan kultivar Gowa dan Pangkajene (Tabel 2 dan Tabel 3).

Tabel 2. Pertumbuhan Panjang Daun (cm) 4 Kultivar Jagung Pulut 


\begin{tabular}{lccccc}
\hline \multirow{2}{*}{ Kultivar } & $\mathbf{5}$ Umur (Minggu) \\
\cline { 2 - 6 } & $\mathbf{2}$ & $\mathbf{4}$ & $\mathbf{6}$ & $\mathbf{8}$ & $\mathbf{1 0}$ \\
\hline \hline \multirow{2}{*}{ Batarakoasa } & $18,98 \pm 9,51$ & $53,67 \pm 15,56$ & $76,40 \pm 9,03$ & $88,40 \pm 13,83$ & $88,40 \pm 13,83$ \\
Gowa & $18,37 \pm 8,16$ & $50,53 \pm 17,92$ & $64,93 \pm 7,43$ & $64,93 \pm 7,43$ & $64,93 \pm 7,43$ \\
Pangkajene & $22,96 \pm 6,62$ & $55,03 \pm 13,48$ & $69,50 \pm 8,08$ & $69,50 \pm 8,08$ & $69,50 \pm 8,08$ \\
Batarakamu & $25,97 \pm 6,43$ & $61,27 \pm 18,18$ & $84,57 \pm 3,14$ & $95,67 \pm 12,30$ & $95,67 \pm 12,30$ \\
\hline \hline
\end{tabular}

Keterangan: Angka dibelakang \pm adalah nilai standar deviasi

Tabel 3.Pertumbuhan Lebar daun (cm) 4 Kultivar Jagung Pulut

\begin{tabular}{lccccc}
\hline \multirow{2}{*}{ Kultivar } & \multicolumn{5}{c}{ Umur (minggu) } \\
\cline { 2 - 6 } \multicolumn{1}{c}{ Batarakoasa } & $\mathbf{2}$ & $\mathbf{4}$ & $\mathbf{6}$ & $\mathbf{8}$ & $\mathbf{1 0}$ \\
Gowa & $1,43 \pm 0,76$ & $4,91 \pm 1,64$ & $7,64 \pm 1,17$ & $8,27 \pm 1,22$ & $8,27 \pm 1,22$ \\
Pangkajene & $2,06 \pm 0,60$ & $6,63 \pm 1,17$ & $7,37 \pm 1,24$ & $7,37 \pm 1,24$ & $7,37 \pm 1,24$ \\
Batarakamu & $2,10 \pm 0,54$ & $6,33 \pm 2,16$ & $8,26 \pm 1,00$ & $8,75 \pm 1,01$ & $8,75 \pm 1,01$ \\
\hline \hline
\end{tabular}

Keterangan: Angka dibelakang \pm adalah nilai standar deviasi

Panjang dan lebar daun selalu bertambah dari waktu ke waktu hingga jagung memasuki fase generatif. Penambahan ukuran panjang dan lebar daun sangat menyolok terjadi pada umur 2 menuju 4 minggu setelah tanam. Penambahan panjang dan lebar daun semakin berkurang terjadi pada umur 6 minggu menuju ke 8 minggu. Ukuran panjang dan lebar daun terpanjang pada Kultivar Batarakamu dan Batarakoasa sedangkan daun terpendek pada kultivar Gowa.

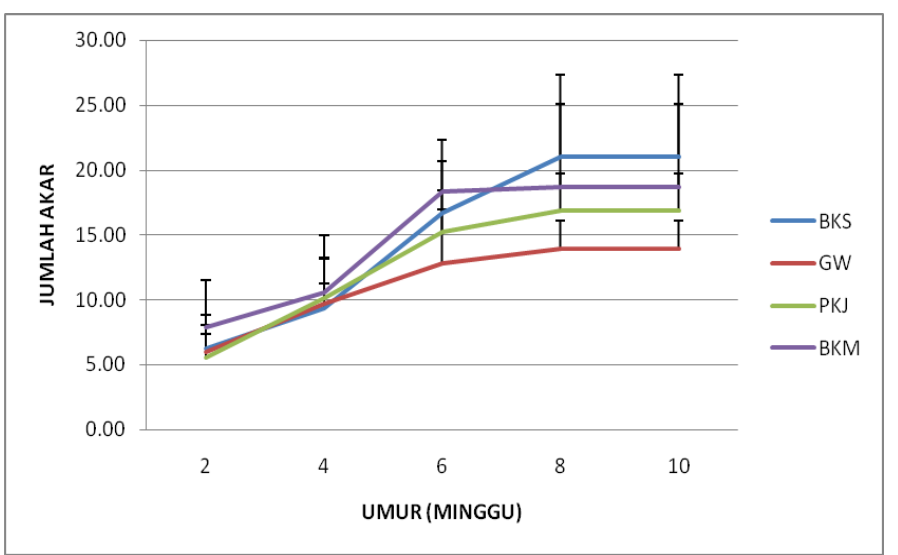

Gambar 4. Kurva pertumbuhan jumlah akar 4 kultivar jagung pulut. $(\mathrm{BKS}=$ Batarakoasa, $\mathrm{GW}=\mathrm{Gowa}, \mathrm{PKJ}=$ Pangkajene, $\mathrm{BKM}=$ Batarakamu)

\section{Pertumbuhan akar}

Penambahan jumlah akar terbesar antara umur 4 dan 6 minggu setelah tanam sedangkan penambahan jumlah akar terkecil terjadi antara umur 6 dan 8 minggu (Gambar 4). Pertumbuhan jumlah akar selalu terjadi selama proses pertumbuhan. Sebuah fenomena yang menarik adalah laju pertambahan panjang akar jagung mulai melambat pada saat tanaman memasuki fase peralihan, dari vegetatif ke generatif. Kultivar Batarakamu dan Batarakoassa memiliki jumlah akar terbanyak sedangkan kultivar Gowa dan Pangkajene memiliki jumlah akar paling sedikit. Nampaknya ada keterkaitan antara 
jumlah akar dan panjang akar. Pada kultivar yang jumlah akarnya banyak memiliki akar yang panjang sedangkan pada kultivar yang jumlah akarnya sedikit cenderung memiliki akar yang pendek (Tabel 4). Jumlah akar yang lebih banyak dan lebih panjang akan berpengaruh terhadap penyerapan hara dari dalam tanah sehingga berpengaruh pada pertumbuhan bagian tanaman lain seperti tinggi batang dan jumlah daun. Kenyataan ini telah ditunjuk oleh kurva pertumbuhan tinggi batang dan jumlah daun yang lebih aktif pada kultivar Batarakamu dan Batarakoasa daripada kultivar Gowa dan Pangkajene (Gambar 2 dan 3).

Tabel 4. Panjang Akar (cm) 4 Kultivar Jagung Pulut.

\begin{tabular}{lccccc}
\hline \multirow{2}{*}{ Kultivar } & \multicolumn{5}{c}{ Umur (minggu) } \\
\cline { 2 - 6 } & $\mathbf{2}$ & $\mathbf{4}$ & $\mathbf{6}$ & $\mathbf{8}$ & $\mathbf{1 0}$ \\
\hline \hline Batarakoasa & $7,71 \pm 1,55$ & $12,13 \pm 7,68$ & $18,72 \pm 2,92$ & $18,72 \pm 2,92$ & $18,72 \pm 2,92$ \\
Gowa & $6,97 \pm 4,45$ & $12,20 \pm 5,48$ & $14,68 \pm 4,88$ & $14,68 \pm 4,88$ & $14,68 \pm 4,88$ \\
Pangkajene & $6,02 \pm 3,11$ & $13,98 \pm 5,09$ & $13,98 \pm 2,25$ & $13,98 \pm 2,25$ & $13,98 \pm 2,25$ \\
Batarakamu & $12,04 \pm 5,84$ & $16,06 \pm 6,53$ & $18,30 \pm 5,13$ & $18,30 \pm 5,13$ & $18,30 \pm 5,13$ \\
\hline \hline
\end{tabular}

Keterangan: Angka dibelakang \pm adalah nilai standar deviasi

\section{Umur Berbunga}

Pada umur 5 minggu setelah tanam jagung pulut kultivar Gowa dan Pangkajene telah berbunga dengan jumlah masing-masing sebanyak $40 \%$ dan $77 \%$ dari populasi tanaman. Pada umur 7 minggu semua tanaman dari kedua kultivar ini telah berbunga mencapai $100 \%$. Kultivar Batarakamu mulai berbunga pada umur
6 minggu dengan jumlah 10\% dari populasi tanaman dan semua tanaman berbunga mencapai $100 \%$ pada umur 8 minggu (Tabel 5). Pada kultivar Batarakoasa, tanaman mulai berbunga pada umur 7 minggu dengan jumlah $20 \%$ dari populasi tanaman dan seluruh tanaman berbunga (100\%) ketika tanaman berumur 10 minggu.

Tabel 5. Persentase Populasi (\%) Jagung Pulut yang Berbunga

\begin{tabular}{lccccc}
\hline \multirow{2}{*}{ Kultivar } & \multicolumn{5}{c}{ Umur (minggu) } \\
\cline { 2 - 6 } & $\mathbf{5}$ & $\mathbf{6}$ & $\mathbf{7}$ & $\mathbf{8}$ & $\mathbf{9}$ \\
\hline \hline Batarakoasa & 0 & 0 & 20 & 80 & 100 \\
Gowa & 40 & 97 & 100 & & \\
Pangkajene & 77 & 87 & 100 & & \\
Batarakamu & 0 & 10 & 27 & 100 & \\
\hline \hline
\end{tabular}

Perbedaan waktu berbunga pada kultivar-kutivar ini dipengaruhi oleh faktor genetik dan didukung oleh kondisi lingkungan yaitu suhu. Leopold \& Kriedemann (1975) melaporkan kecepatan berbunga ditentukan oleh umur dan ukuran tanaman. Keduanya menambahkan bahwa suhu rendah berpengaruh pada kecepatan waktu berbunga pada tanaman. Faktor suhu rendah nampaknya bukan menjadi penyebab perbedaan kecepatan berbunga antara kultivar Gowa dan Pangkajene, dengan kultivar Batarakamu dan Batarakoassa, sebab keempat kultivar jagung pulut ini ditanam secara bersama pada satu lokasi di Cibinong, Bogor; dan memperoleh lingkungan tumbuh yang sama. Hartmann et al, (1959) menyampaikan bahwa suatu tanaman tidak akan berbunga sebelum menyelesaikan fase vegetatifnya. Merujuk pada pendapat Leopold \& Kriedemann (1975) tentang ukuran tanaman, maka diketahui bahwa Kultivar Pangkajene dan Gowa, dengan perawakan tanaman yang rendah dan kecil, memiliki masa vegetative lebih singkat dibandingkan dengan kultivar Batarakamu dan Batarakoassa sehingga memiliki waktu berbunga lebihawal. 


\section{Pertumbuhan Maksimum Pada Fase Vegetatif}

Pada tanaman jagung pertumbuhan vegetatif akan terhenti setelah tanaman menghasilkan bunga. Pada saat itu pertumbuhan vegetatif mencapai pertumbuhan maksimum. Analisis statistika pertumbuhan maksimum pada keempat kultivar jagung pulut dari Sulawesi Selatan disampaikan pada Tabel 6.

Terdapat persamaan pola pertumbuhan antara kultivar jagung berumur genjah dan berumur dalam. Pertumbuhan tinggi tanaman secara pesat mulai terjadi di umur 4 minggu setelah tanam. Tetapi terdapat perbedaan waktu berakhirnya fase pertumbuhan tersebut. Pada Kultivar Pangkajene dan Gowa yang berumur genjah, munculnya malai pada $50 \%$ populasi terjadi di umur 5-6 minggu. Pada saat itu, pertumbuhan vegetatif, meliputi jumlah daun, ukuran daun, dan diameter batang telah berhenti; demikian juga dengan jumlah dan panjang akar. Tetapi tinggi tanaman tetap meningkat untuk memperpanjang tangkai malai. Pertumbuhan tinggi tanaman berhenti pada umur 8 minggu setelah tanam, pada saat mulai pengisian tongkol. Ini menandakan energi pertumbuhan tanaman pada saat itu dialihkan untuk pembentukan organ generatif tanaman.

Pada kultivar Batarakamu dan Batarakoasa yang berumur dalam memiliki masa vegetatif yang lebih lama dibandingkan dengan kultivar berumur genjah. Masa vegetatif yang lebih panjang memberikan laju pertambahan ukuran organ vegetatif, seperti jumlah daun, panjang dan lebar daun, dan diameter batang yang lebih besar dibandingkan dengan kultivar berumur genjah (Gambar 5).

Pada parameter jumlah akar dan panjang akar diketahui berbeda tidak nyata, tapi ada kecenderungan kultivar Batarakamu memiliki akar lebih panjang dan lebih banyak dari ketiga kultivar lain (Gambar 6b). Perbedaan-perbedaan yang terjadi pada parameter pertumbuhan ini akan berpengaruh terhadap produksi berupa biji jagung. Dengan masa vegetatif yang lama tersebut, ukuran malai dan tongkol yang dihasilkan juga lebih besar (Gambar 6a).

Tabel 6. Analisis Pertumbuhan Maksimum 4 Kultivar Jagung Pulut

\begin{tabular}{lcccccccc}
\hline \hline Kultivar & $\begin{array}{c}\text { Tinggi } \\
(\mathbf{c m})\end{array}$ & $\begin{array}{c}\text { Diameter } \\
\text { Batang } \\
(\mathbf{c m})\end{array}$ & $\begin{array}{c}\text { Jumlah } \\
\text { Daun }\end{array}$ & $\begin{array}{c}\text { Panjang } \\
\text { Daun }(\mathbf{c m})\end{array}$ & $\begin{array}{c}\text { Lebar } \\
\text { Daun } \\
(\mathbf{c m})\end{array}$ & $\begin{array}{c}\text { Luas } \\
\text { Daun } \\
\text { Total } \\
\left(\mathbf{c m}^{2}\right)\end{array}$ & $\begin{array}{c}\text { Panjang } \\
\text { Akar }(\mathbf{c m})\end{array}$ & $\begin{array}{c}\text { Jumlah } \\
\text { Akar }\end{array}$ \\
\hline Batara & $198,03 \mathrm{a}$ & $1,8833 \mathrm{ab}$ & $11,767 \mathrm{a}$ & $89,50 \mathrm{a}$ & $8,4067 \mathrm{a}$ & $3735 \mathrm{ab}$ & $18,510 \mathrm{a}$ & $18,113 \mathrm{a}$ \\
Koasa & & & & & & & & \\
Batara & $224,93 \mathrm{a}$ & $2,1567 \mathrm{a}$ & $11,700 \mathrm{a}$ & $96,70 \mathrm{a}$ & $8,9067 \mathrm{a}$ & $5878 \mathrm{a}$ & $23,300 \mathrm{a}$ & $22,443 \mathrm{a}$ \\
Kamu & & & & & & & & \\
Pangkajene & $143,90 \mathrm{~b}$ & $1,7200 \mathrm{cb}$ & $8,833 \mathrm{~b}$ & $69,50 \mathrm{~b}$ & $7,3733 \mathrm{~b}$ & $2324 \mathrm{ab}$ & $17,400 \mathrm{a}$ & $17,557 \mathrm{a}$ \\
Gowa & $127,80 \mathrm{~b}$ & $1,4200 \mathrm{c}$ & $8,133 \mathrm{~b}$ & $64,93 \mathrm{~b}$ & $6,4467 \mathrm{c}$ & $1573 \mathrm{~b}$ & $15,623 \mathrm{a}$ & $14,667 \mathrm{a}$ \\
\hline \hline
\end{tabular}

Keterangan : Angka yang diikuti dengan huruf yang sama dalam satu kolom berarti berbeda tidak nyata pada taraf Uji DMRT 5\%

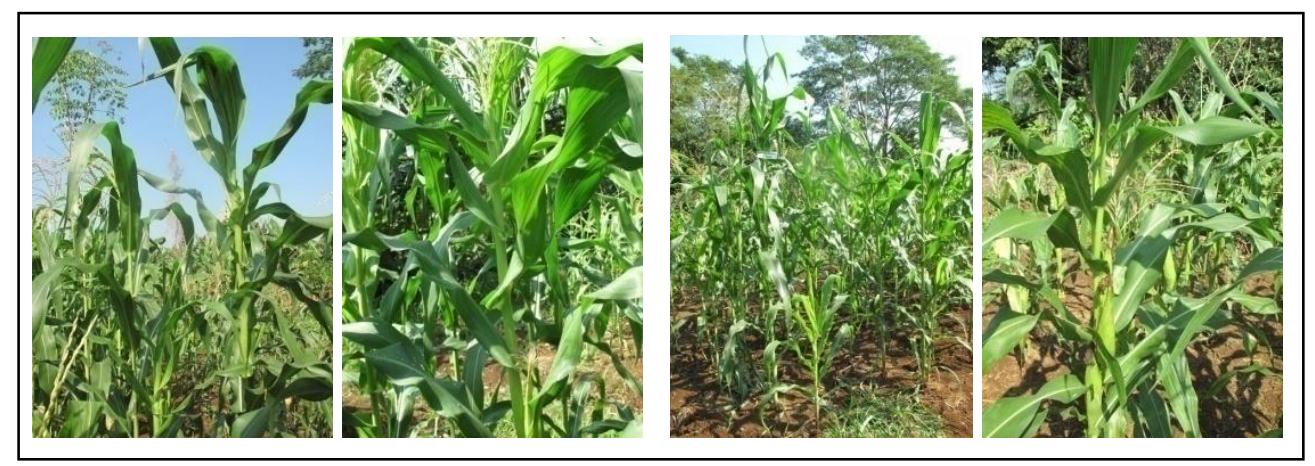

Gambar 5. Pertumbuhan vegetatif kultivar Batarakamu dan Batarakoasa, Gowa dan Pangkajene 


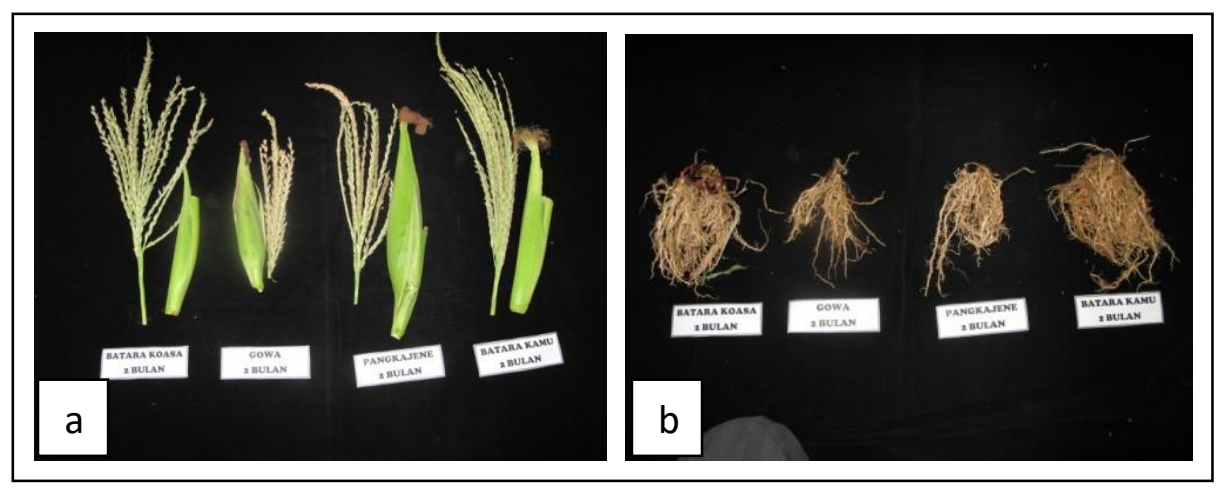

Gambar 6. a. Perbandingan Malai dan kelobot pada 4 kultivar jagung. b. Perbandingan Panjang dan jumlah akar pada 4 kultivar jagung.

\section{Berat Kering}

Berat kering bagian-bagian tanaman pada saat panen tertera pada Tabel 7. Kultivar Batarakamu memiliki berat kering lebih besar dibandingkan dengan ketiga kultivar lain. Perbedaan berat kering ini dipengaruhi faktor genetik yang dimiliki oleh setiap kultivar dan tempat tumbuh tanaman jagung. Kultivar Batarakamu dan Batarakoasa memiliki perawakan tinggi dengan batang besar serta daun yang panjang.

Tabel 7. Berat Kering Empat Kultivar Jagung Lokal pada Saat Panen

\begin{tabular}{|c|c|c|c|c|c|c|}
\hline Kultivar & $\begin{array}{l}\text { Batang } \\
\text { (gram) } \\
\end{array}$ & $\begin{array}{l}\text { Daun } \\
\text { (gram) } \\
\end{array}$ & $\begin{array}{l}\text { Malai } \\
\text { (gram) }\end{array}$ & $\begin{array}{l}\text { Akar } \\
\text { (gram) }\end{array}$ & $\begin{array}{l}\text { Berat kelobot } \\
\text { (gram) }\end{array}$ & Total (gram) \\
\hline Batarakoasa & $39,770 \mathrm{ab}$ & $26,730 \mathrm{a}$ & $2,8700 \mathrm{~b}$ & $1717,270 \mathrm{ab}$ & $128,68 \mathrm{ab}$ & 210,32 \\
\hline Batarakamu & $54,050 \mathrm{a}$ & $27,657 \mathrm{a}$ & $3,9400 \mathrm{a}$ & $23,653 \mathrm{a}$ & $176,06 \mathrm{a}$ & 285,36 \\
\hline Pangkajene & $26,250 \mathrm{bc}$ & $12,853 \mathrm{~b}$ & $1,8867 \mathrm{c}$ & $10,667 \mathrm{bc}$ & 98,42 bc & 150,07 \\
\hline Gowa & $17,323 \mathrm{c}$ & $8,370 \mathrm{~b}$ & $1,3233 \mathrm{c}$ & $5,293 c$ & $67,17 \mathrm{c}$ & 99,48 \\
\hline
\end{tabular}

Keterangan : Angka yang diikuti dengan huruf yang sama dalam satu kolom berarti berbeda tidak nyata pada taraf Uji DMRT 5\%

Millthorpe dan Moorby (1979) serta Goldsworthy \& Fisher (1992) melaporkan bahwa berat kering tanaman dipengaruhi oleh peningkatan indeks luas daun, keteraturan daundaun pada batang dan pengaruhnya terhadap penerimaan cahaya matahari dalam melakukan fotosintesa. Gardner et al, (1991) melaporkan bahwa hasil berat kering total adalah hasil efisiensi penyerapan dan pemanfaatan radiasi matahari oleh daun. Penyerapan dan pemanfaatan radiasi matahari tergantung juga pada luas daun, ketebalan daun dan indeks luas daun (Tabel 8).

Indeks luas daun dapat digambarkan dari pengukuran panjang, lebar daun, dan jumlah duan tanaman. Polnaya dan Patty (2012) menyatakan bahwa jumlah daun tanaman menggambarkan luas daun total per tanaman. Dari Tabel 8 diketahui bahwa luas daun spesifik, indeks luas daun dan indeks ketebalan daun tertinggi terdapat pada kultivar Batarakamu.

Tabel 8. Data Nisbah Berat Daun, Indeks Luas daun dan indeks Ketebalan daun pada 4 kultivar jagung Pulut dari Sulawesi Selatan.

\begin{tabular}{lcccc}
\hline \hline \multicolumn{1}{c}{ Kultivar } & $\begin{array}{c}\text { Nisbah Berat } \\
\text { Daun (NBD) }\end{array}$ & $\begin{array}{c}\text { Luas Daun } \\
\text { Spesifik (LDS) }\end{array}$ & $\begin{array}{c}\text { Indeks Luas Daun } \\
\text { (ILD) }\end{array}$ & $\begin{array}{c}\text { Indeks Ketebalan } \\
\text { daun (IKD) }\end{array}$ \\
\hline \hline Batarakoasa & 0,1271 & 139,730 & 0,933 & 17,76 \\
Batarakamu & 0,0970 & 212,532 & 1,470 & 20,62 \\
Pangkajene & 0,0856 & 180,814 & 0,581 & 15,48 \\
Gowa & 0,0841 & 187,933 & 0,393 & 15,81 \\
\hline \hline
\end{tabular}


Hal ini menunjukkan bahwa penyerapan dan pemanfaatan radiasi matahari tertinggi dilakukan oleh kultivar Batarakamu. Gardner et al, (1991) melaporkan bahwa asimilasi maksimum tercapai pada indeks luas daun antara 3,0 dan 5,0. Muhadjir (1988) melaporkan ILD pada jagung melebihi dari 3,0 akan menyerap cahaya matahari sekitar $95 \%$ sedangkan ILD lebih dari 5,0 akan menyebabkan penurunan penyerapan cahaya matahari karena daun pada batang terjadi tumpang-tindih satu dengan yang lain. Heddy (2001) menjelaskan bahwa leaf area ratio (LAR) yang dalam Tabel 8 adalah IKD merupakan gambaran rasio fotosintesis dari bahan-bahan yang tersedia dalam tanaman yang melakukan respirasi.

\section{Produksi Jagung}

Beberapa parameter pengamatan yang berkaitan dengan produksi jagung adalah, kelobot, tongkol, jumlah biji per tongkol, berat biji dan produksi biji per meter bujur sangkar $\left(\mathrm{m}^{2}\right)$. Pada Tabel 9 berikut akan diperlihatkan ukuran dan berat kelobot dan tongkol jagung.

Tabel 9. Ukuran Kelobot dan tongkol dari 4 kultivar jagung lokal

\begin{tabular}{lcccccc}
\hline \hline Kultivar & $\begin{array}{c}\text { Panjang } \\
\text { Kelobot } \\
(\mathbf{c m})\end{array}$ & $\begin{array}{c}\text { Diameter } \\
\text { Kelobot } \\
(\mathbf{c m})\end{array}$ & $\begin{array}{c}\text { Berat } \\
\text { Kelobot } \\
\text { (gram) }\end{array}$ & $\begin{array}{c}\text { Panjang } \\
\text { Tongkol }(\mathbf{c m})\end{array}$ & $\begin{array}{c}\text { Diameter } \\
\text { tongkol } \\
(\mathbf{c m})\end{array}$ & $\begin{array}{c}\text { Berat Tongkol } \\
\text { (gram) }\end{array}$ \\
\hline Batarakoasa & $23,423 \mathrm{~b}$ & $4,8733 \mathrm{~b}$ & $128,68 \mathrm{ab}$ & $13,7433 \mathrm{ab}$ & $4,4467 \mathrm{a}$ & $103,38 \mathrm{~b}$ \\
Batarakamu & $26,987 \mathrm{a}$ & $5,5667 \mathrm{a}$ & $176,06 \mathrm{a}$ & $15,4367 \mathrm{a}$ & $4,7833 \mathrm{a}$ & $142,28 \mathrm{a}$ \\
Pangkajene & $23,363 \mathrm{~b}$ & $3,9733 \mathrm{c}$ & $98,42 \mathrm{bc}$ & $12,6433 \mathrm{~b}$ & $3,3800 \mathrm{~b}$ & $59,85 \mathrm{c}$ \\
Gowa & $21,673 \mathrm{~b}$ & $3,5367 \mathrm{c}$ & $67,17 \mathrm{c}$ & $12,4733 \mathrm{~b}$ & $3,000 \mathrm{~b}$ & $47,06 \mathrm{c}$ \\
\hline \hline
\end{tabular}

Keterangan : Angka yang diikuti dengan huruf yang sama dalam satu kolom berarti berbeda tidak nyata pada taraf Uji DMRT 5\%

Dari Tabel 9 diketahui bahwa ukuran kelobot dan tongkol jagung, kultivar Batarakamu lebih besar dan lebih berat dari ketiga kultivar lain. Kelobot dan tongkol pada kultivar Gowa memiliki ukuran kecil dan berat yang teringan. Perbedaan ukuran kelobot dan tongkol jagung dipengaruhi oleh faktor genetik dan lingkungan tempat tumbuh jagung tersebut. Rouf et al, (2010) juga melakukan karakterisasi tongkol jagung pada 2 kultivar jagung pulut yang berasal dari Gorontalo, yang menunjukkan terdapat perbedaan pada panjang dan berat tongkol dari kedua kultivar jagung pulut tersebut. Apabila dibandingkan dengan kultivar Batarakamu dan Batarakoasa maka kedua kultivar jagung pulut dari Gorontalo memiliki ukuran tongkol dan berat tongkol yang lebih kecil. Gardner et al, (1991) melaporkan bahwa untuk mendapatkan hasil panen yang besar membutuhkan indeks luas daun yang besar sehingga cepat untuk menyerap cahaya matahari guna memproduksi berat kering yang maksimum. Pada Tabel 8 kultivar Batarakamu memiliki indeks luas daun tertinggi yaitu 1, 470 dibandingkan dengan 3 kultivar lainnya. Kelobot dan tongkol jagung yang terletak di tengah batang menyimpan cadangan makanan dari sebagian besar daun (80\%) yang ada di atas kelobot (bunga betina). Batarakamu memiliki jumlah daun yang lebih banyak dan lebih panjang (Gambar 3 \&Tabel 6) dari ketiga kultivar lainnya. 

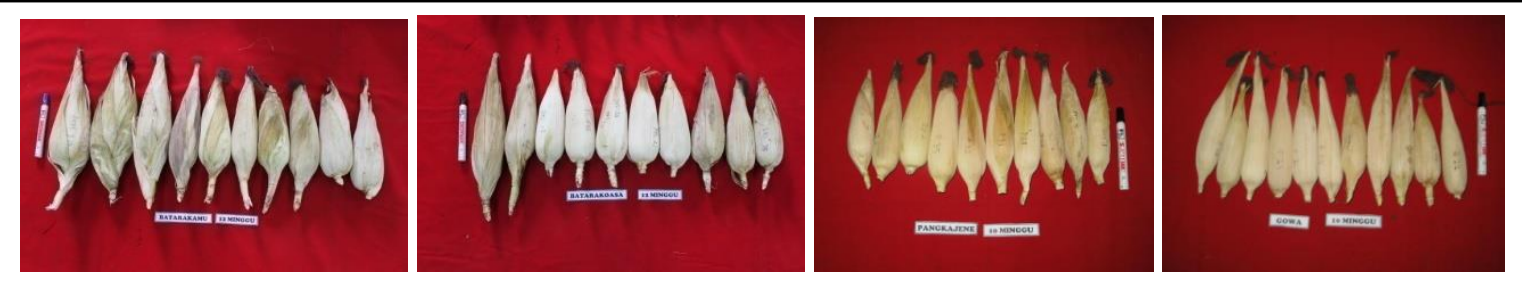

Gambar 7. Ukuran kelobot dari 4 kultivar jagung lokal (dari kiri ke kanan) Batarakamu, Batarakoasa, Pangkajene dan Gowa

Pengamatan berat biji per tongkol pada 4 kultivar jagung pulut diketahui juga bervariasi selain dipengaruhi oleh ukuran tongkol yang berbeda juga terdapat bagian-bagian tongkol yang tidak ditumbuhi biji jagung (ompong). Pada Tabel 10 disajikan persentase tongkol utuh dan ompong serta berat bijinya.

Tabel 10. Persentase Tongkol Utuh dan Ompong pada 4 kultivar jagung pulut

\begin{tabular}{|c|c|c|c|c|c|}
\hline \multirow[b]{2}{*}{ Kultivar } & \multicolumn{2}{|c|}{ Utuh } & \multicolumn{2}{|c|}{ Ompong } & \multirow[b]{2}{*}{$\begin{array}{c}\text { Rata-rata berat } \\
\text { biji per tongkol } \\
\text { (gram) }\end{array}$} \\
\hline & $\begin{array}{c}\text { Persentase } \\
(\%)\end{array}$ & $\begin{array}{c}\text { Berat Biji / } \\
\text { tongkol } \\
\text { (gram) }\end{array}$ & $\begin{array}{c}\text { Persentase } \\
(\%)\end{array}$ & $\begin{array}{c}\text { Berat biji / } \\
\text { tongkol } \\
\text { (gram) }\end{array}$ & \\
\hline Batarakoasa & 76,67 & $165,30 \mathrm{a}$ & 23,33 & $37,00 \mathrm{ab}$ & $101,15 \mathrm{a}$ \\
\hline Batarakamu & 84,61 & $173,90 \mathrm{a}$ & 15,39 & $55,80 \mathrm{a}$ & $114,85 \mathrm{a}$ \\
\hline Pangkajene & 46,66 & $55,42 \quad b$ & 53,34 & $30,12 \mathrm{bc}$ & $42,77 \quad b$ \\
\hline Gowa & 36,66 & $58,78 \quad b$ & 63,34 & $25,50 \mathrm{c}$ & $42,14 \quad b$ \\
\hline
\end{tabular}

Keterangan : Angka yang diikuti dengan huruf yang sama dalam satu kolom berarti berbeda tidak nyata pada taraf Uji DMRT 5\%

Dari populasi panenan tongkol jagung diketahui bahwa rata-rata persentase tongkol yang utuh bervariasi. Kultivar Batarakamu dan Batarakoasa memiliki persentase tongkol utuh lebih tinggi daripada kultivar Pangkajene dan Gowa. Keutuhan dan keompongan tongkol berpengaruh terhadap jumlah dan berat biji per tongkol. Oleh karena itu produksi biji pada setiap kultivar tergantung pada genetik dan faktor lingkungan. Tollenaar (1977) melaporkan bahwa faktor utama yang menentukan jumlah biji dalam tanaman jagung yaitu jumlah penyinaran yang diserap oleh tanaman selama periode pembungaan. Goldsworthy \& Fisher (1992) menjelaskan bahwa tongkol secara terus menerus mengalami kehilangan jumlah biji yang tumbuh setelah perambutan. Umumnya biji-biji muda yang tumbuh pada ujung tongkol mengalami pengguguran. Pengguguran biji muda terjadi akibat pertumbuhan biji terganggu karena kekeringan (Kartasapoetra, 1988). Kebutuhan air tertinggi pada tanaman semusim umumnya terjadi pada fase generatif mulai awal pembungaan hingga pembentukan buah atau biji. Jika pada fase tersebut ketersediaan air terbatas sering terjadi penurunan produksi. Sutoro et al, (1988) menjelaskan bahwa distribusi ideal ketersediaan air selama fase pertumbuhan vegetatif hingga pengisian biji berkisar $200 \mathrm{~mm}$ per bulan. Bagi kultivar-kultivar jagung lokal yang berasal dari daerah kering dan dibudidayakan pada musim kering, tentunya distribusi ideal ketersediaan air tidak akan mencukupi. Oleh karena itu kultivar jagung lokal yang dapat memberikan hasil pada musim kemarau merupakan kemampuan kultivar tersebut untuk beradaptasi dengan kondisi iklim kering. Maruapey (2012) menjelaskan bahwa kekurangan kalium dalam tanaman jagung juga menjadi penyebab ujung tongkol jagung tidak terisi penuh dengan biji jagung karena biji jagung tidak melekat kuat pada tongkolnya sehingga terjadi pengguguran. Pada Gambar 8 terlihat variasi tongkol keempat kultivar jagung lokal dari Sulawesi selatan. 


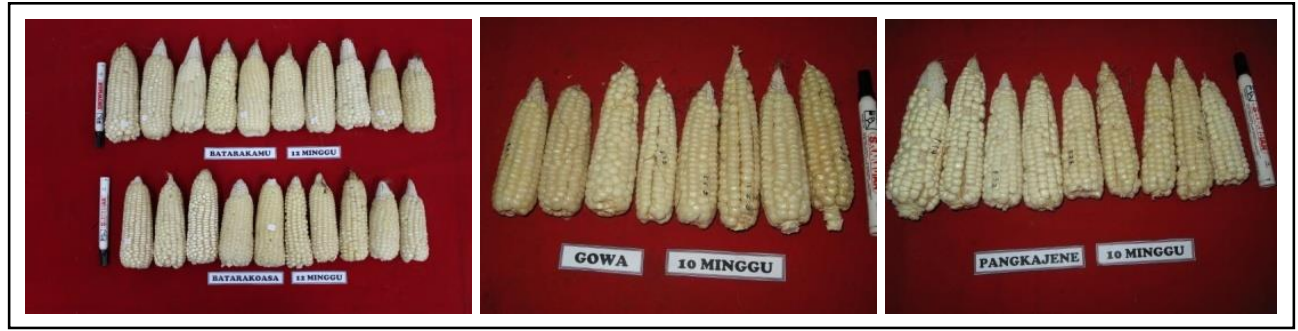

Gambar 8. Tongkol dan biji jagung yang tumbuh pada tongkol keempat kultivar

Data produksi biji jagung kering per satuan $\mathrm{m}^{2}$ menunjukkan kultivar Batarakamu dan
Batarakoasa lebih tinggi dari kultivar Pangkajene dan Gowa (Tabel 11).

Tabel 11. Produksi Jagung Lokal (pulut) dari Provinsi Sulawesi Selatan.

\begin{tabular}{lccccc}
\hline \hline Kultivar & $\begin{array}{c}\text { Kadar air biji } \\
\text { Segar } \\
(\%)\end{array}$ & $\begin{array}{c}\text { Berat 100 } \\
\text { biji kering } \\
\text { (gram) }\end{array}$ & $\begin{array}{c}\text { Produksi } \\
\text { biji per } \mathbf{~ m}^{2} \\
\text { (gram) }\end{array}$ & $\begin{array}{c}\text { Berat Kering biji } \\
\text { per tanaman } \\
\text { (gram) }\end{array}$ & $\begin{array}{c}\text { Indeks } \\
\text { Panen }\end{array}$ \\
\hline \hline Batarakoasa & $34,08 \mathrm{c}$ & 38,70 & $1983,60 \mathrm{~b}$ & $66,69 \mathrm{~b}$ & 0,3171 \\
Batarakamu & $35,11 \mathrm{~b}$ & 52,50 & $2086,80 \mathrm{a}$ & $74,53 \mathrm{a}$ & 0,2611 \\
Pangkajene & $43,26 \mathrm{a}$ & 28,90 & $665,04 \mathrm{~d}$ & $24,27 \mathrm{~d}$ & 0,1617 \\
Gowa & $31,73 \mathrm{~d}$ & 32,30 & $705,36 \mathrm{c}$ & $28,76 \mathrm{c}$ & 0,2891 \\
\hline
\end{tabular}

Keterangan: Angka yang diikuti dengan huruf yang sama dalam satu kolom berarti berbeda tidak nyata pada taraf Uji DMRT 5\%

Perbedaan hasil atau produksi biji pada empat kultivar jagung lokal tersebut dipengaruhi oleh genetik (Goldsworthy \& Fisher, 1992). Umumnya produksi biji yang tinggi berkaitan langsung luas daun. Pada kultivar Batarakamu memiliki luas daun spesifik (LDS) dan indeks Luas daun (ILD) yang lebih besar (Tabel 8) dibandingkan dengan tiga kultivar lainnya sehingga kultivar Batarakamu lebih mampu untuk menyekap sinar matahari yang berfungsi dalam kegiatan fotosintesis.

Indeks panen (IP) setiap kultivar juga bervariasi. Indeks panen tertinggi pada kultivar Batarakoasa sedang terendah pada kultivar Pangkajene. Indeks Panen lebih banyak dipengaruhi oleh pertumbuhan vegetatif terutama daun dan produksi biji per tanaman. Di daerah sedang indeks panen jagung dapat mencapai $0,50-0,56$ sedangkan untuk jagung tropik indeks panennya mencapai 0,39 (Muhadjir, 1988). Gardner et al, (1991) mengatakan indeks panen ini menunjukkan bahwa ada perpindahan bahan kering dari organorgan tanaman yang lain menuju bagian tanaman yang dipanen.Peningkatan hasil panen (produksi biji) pada satuan luasan lahan selain ditentukan oleh kondisi pertumbuhan tanaman jagung sejak awal hingga fase pengisian biji, juga dipengaruhi pula oleh kerapatan tanaman, kesuburan lahan serta penetapan waktu tanam yang tepat.

\section{Simpulan}

Pada eksplorasi ini telah terkoleksi benih 4 kultivar jagung pulut dari provinsi Sulawesi Selatan yaitu kultivar Gowa, kultivar Pangkajene, kultivar Batarakamu dan kultivar Batarakoasa. Kultivar Batarakamu dan Batarakoasa memiliki habitus tanaman lebih kekar, lebih tinggi, dan berumur dalam sedeangkan kultivar Gowa dan Pangkajene berumur genjah. Berdasarkan tingkat produksi tongkol untuk pangan dan biomass sebagai sumber pakan, kultivar Batarakamu direkomendasikan sebagai kultivar terbaik dari 4 kultivar jagung pulut yang telah diuji.

\section{Daftar Pustaka}

Falconer, D.S., T.F.C, Mackay. 1996. Introduction to Quantitative Genetics. Fourth Edition. Longman Group. Malaysia. 464 p.

Fiddin, F.N., I, Yulianah., dan A.N, Sugiharto. 2018. Keragaan Beberapa Galur Jagung Ketan (Zea mays 


\section{Albert Husein Wawo dkk.}

L. certain K.) Pada Generasi Keempat (S4). Jurnal Produksi tanaman 6(2):178-187.

Gardner, F.P., Pearce, R.B \& Mitchell, R.L. 1991. Physiology of Crops Plants. Diterjemahkan oleh Herawati Susilo \& Subiyanto dengan judul: Fisiologi Tanaman Budidaya. Penerbit Universitas Indonesia. 428 hal.

Goldsworthy, P.R \& Fisher, N.M. 1992. The Physiology of Tropical Field Crops. Diterjemahkan oleh Tohari dan Soedaroedjian dengan judul : Fisiologi Tanaman Budidaya Tropik. Gadjah Mada University Press. ISBN 9794202320. 874 hal.

Hanafiah, K. A. 2002. Rancangan Percobaan. Teori \& Aplikasi. Edisi Ketiga. PT.RajaGrafindo Persada, Jakarta. ISBN 979-421-295-4. 299 hal.

Hartmann, H.T., D.E, Kester., F.T, Davis Jr., R.L, Geneve. Plant Propagation: Principles and practices. Sixth edition. Prentice Hall. 770 p.

Heddy, S. 1999. EkoFisiologi Tanaman. Suatu Kajian Kuantitatif Pertumbuhan Tanaman. PT. RajaGrafindo Persada: Jakarta. ISBN 979-421-5635. 96 hal.

Herawati., M, Riadi dan M, Farid Bdr. 2015. Karakter Pertumbuhan dan Produksi Beberapa Jagung Pulut Lokal (Zea mays Ceratina) Pada Dua Takaran Pupuk Posfor. Prosiding Seminar Nasional Serealia 2015. ISBN 978-979-8940-40-8. Hal 195-204.

Juhaeti, T., N, Hidayati., dan M, Rahmansyah. 2013. Pertumbuhan dan Produksi Jagung Pulut Lokal Sulawesi Selatan yang Ditanam di Polibag Pada Berbagai Kombinasi Perlakuan Pupuk Organik. Jurnal Biologi Indonesia. 9(2):219-232.

Juhriah., Baharuddin., Musa, Y., dan Pabendon, M. B. 2013. Keragaman Fenotipik Plasma Nutfah Jagung Lokal Sulawesi Barat dan Sulawesi Tengah Dengan Jagung Asal Cimmyt Untuk Seleksi Jagung Provit A. Jurnal Sains dan Teknologi,13(1). ISSN 14114674. Hal 26-32.
Kartasapoetra, A.G. 1988. Teknologi Budidaya tanaman Pangan di Daerah Tropik. Bina Aksara: Jakarta. 419 hal.

Leopold, A.G and P.E, Kriedemann. 1975. Plant Growth And Development. Second Edition. McGrawHill.Inc. Printed in USA. 545 pp.

Lestari, M dan S, Farid. 2017. Potret jagung Indonesia: Menuju Swasembada tahun 2017. Badan Pengkajian dan Pengembangan Kebijakan Perdagangan. Kementerian Perdagangan. http://bppp.kemendag.go.id/media_content/2017/08 /Potret_Jagung_Indonesia-

Menuju_Swasembada_Tahun_2017.pdf [diunduh 26 Juni 2019].

Maruapey, A. 2012. Pengaruh Pupuk Kalium Terhadap Pertumbuhan Dan Produksi Produksi Berbagai Jagung Pulut ( Zea Mays Ceratina. L). Jurnal Ilmiah Agribisnis dan Perikanan, 5(2). ISSN 19796072. Hal 34-45.

Menteri Negara Riset dan Teknologi. 1981. Permasalahan Lahan Serealia (Padi, Jagung, Sorghum, Gandum) di Indonesia. Laporan Pertemuan Kerja. Pepunas 1 - Ristek, Busarman: Jakarta. 31 hal.

Millthorpe, F.L and Moorby, J. 1979. An Introduction to Crop Physiology. 2 ${ }^{\text {nd }}$ Ed. Cambridge University Press, Cambridge.

Muchtar., Tina, F., Andi, I dan Musyita, M. 2018. Pengaruh Implementasi Sistem Irigasi Sprinkler, Kompos dan Biochar terhadap Pertumbuhan dan Hasil Jagung Pulut di Lahan Kering Kabupaten Sigi, Sulawesi Tengah. Prosiding Seminar Nasional Fakultas Pertanian UNS dalam Rangka Dies Natalis UNS Ke 42. 2(1). E-ISSN: 2615-7721P-ISSN: 2620-8512. Hal 51-59.

Muhadjir, F. 1988. Karakteristik Tanaman Jagung. Dalam Jagung. Balai Penelitian Dan Pengembangan Pertanian, Pusat Penelitian dan Pengembangan Pertanian: Bogor. Hal 33-48. 
Pakpahan, A. 2007. Freedom for Farmer Freedom for All. Ideals Agro Abrar. Gedung Alumni IPB: Bogor. ISSN 1907-8676. $331 \mathrm{pp.}$

Polnaya, F and J.E, Patty. 2012. Kajian Pertumbuhan dan Produksi Varietas Jagung Lokal dan Kacang Hijau Dalam Sistem Tumpangsari. Agrologia. Jurnal Ilmu Budidaya Tanaman. 1(1):42-51.

Rouf, A.A., Annas, Z dan Dahlan, W. 2010. Pengkajian Pemurnian Benih Jagung Pulut di Provinsi Gorontalo. Prosiding Pekan Serealia Nasional. ISSN : 978-979-8940-29-3. Hal 117-121.

Sabarella., W.B, Komalasari., S, Wahyuningsih., M, Manurung., Sehusman., Rinawati., Y, Supriyati. 2018. Buletin Konsumsi Pangan. 9(1). http://epublikasi.setjen.pertanian.go.id/epublikasi/b uletin/konsumsi/2018/Buletin_Konsumsi_Pangan_S emester_1_2018/files/assets/basic-html/page2.html. [diunduh 26 Juni 2019].

Safuan, L., Boer, D., T, Wijayanto., N, Susanti. 2014. Analisis Variabilitas Kultivar Jagung Pulut (Zea mays ceritina Kulesh) Lokal Sulawesi Tenggara. Jurnal Agroteknos, 4(2):108-112.

Saharuddin dan Nirwana. 2008. Jagung PUMA Silangan Jagung Pulut dan Jagung Manis. Diakses http://ketahananpangannunukan.blogspot.com/2009 109/jagung-puma-silangan-jagung-pulut-dan.html tanggal 19 Juni 2019.

Sitompul, S.M dan Guritno, B. 1995. Analisis Pertumbuhan Tanaman. Gadjah Mada University Press: Yogyakarta. Hal 202-210.

Sutoro., Y, Soelaeman dan Iskandar. 1988. Budidaya Tanaman Jagung. Dalam Jagung. Balai Penelitian Dan Pengembangan Pertanian, Pusat Penelitian dan Pengembangan Pertanian: Bogor. Hal 49-66.

Tengah, J., Tumbelaka, S dan Toding, M. 2017. Pertumbuhan dan Produksi Jagung Pulut Lokal (Zea Mays Ceratina Kulesh) Pada Beberapa Dosis Pupuk NPK. Jurnal Ilmiah Fakultas Pertanian Universitas Sam Ratulangi, 1(1). Diakses https://ejournal.unsrat.ac.id/index.php/cocos/article /view/14909 tanggal 28 Juni 2019.

Tollenaar, M. 1977. Sink-Source Relationships During Reproductive Development in Maize. A. review. Maydica, XXII. 49-75 p.

Wawo, A.H., Silverstone, S \& Lestari, P. 2018. Comparison Growth and Production Between Maize Variety Seperior Natiopnal and Local Variety in Penjarakan Village, Bali. International Prosiding of International Symposium on Bioeconomics of Natural Resources Utilization (ISBINARU) 2017 . Center for Plant Conservation Botanic Gardens-LIPI, Bogor, Indonesia, 12-14 October. ISBN 978-979-8539-77-0 p.35 -43

Wijayanto, T. 2007. Karakterisasi Sifat-Sifat Agronomi Beberapa Nomor Koleksi Sumber Daya Genetik Jagung Sulawesi. Jurnal Penelitian dan Informasi Pertanian, 11(2). ISBN 1410-0029. Hal 75-83.

Wirosoedarmo, R., A.T, Sutanhaji., E, Kurniati., dan R, Wijayanti. 2011. Evaluasi Kesesuaian Lahan Untuk Tanaman Jagung Menggunakan Metode Analisis Spasial. Agritech 31(1):71-78.

Yasin, M. H. G., Singgih, S., M, Hamdani., Santoso, S.B. 2007. Jagung : Teknik Produksi dan Pengembangan. Pusat Penelitian dan Pengembangan Tanaman Pangan, Departemen Pertanian: Bogor. Hal 42-54.

Yasin, M.H.G., Singgih, S., M, Hamdani., Santoso, S.B. 2016. Keragaman Hayati Plasma Nutfah Jagung. Dalam Jagung: Teknik Produksi dan Pengembangan. http://balitsereal.litbang.pertanian.go.id/wpcontent/uploads/2016/11/enam.pdf [diunduh 26 Juni 2019].

Yasin, M.H.G., Suarni., S.B, Santoso., Faesal., A.H, Talanca., M.J, Mejaya. 2017. Stabilitas Hasil Jagung Pulut Varietas Bersari Bebas Pada Dataran Rendah Tropis. Penelitian Pertanian Tanaman Pangan 1(3): 223-232. 